\title{
Infiltration Characteristics of Granitic Residual Soil of Various Weathering Grades
}

\author{
${ }^{1}$ Faisal Hj. Ali, ${ }^{2}$ Bujang B.K. Huat and ${ }^{1}$ Low T.H. \\ ${ }^{1}$ Department of Civil Engineering, University of Malaya, 50603 Kuala Lumpur, Malaysia \\ ${ }^{2}$ Department of Civil Engineering, University Putra Malaysia \\ 43400 UPM Serdang, Selangor, Malaysia
}

\begin{abstract}
This study presents the result of a field study on the infiltration characteristics of cut a slope in granitic residual soil of various weathering grades. Granitic residual soil of weathering grade IV is found to have the highest infiltration rate. Water infiltration is found to increase from grade VI to IV and decrease from grade IV to grade III. Water infiltration is found to increase with the increase in soil porosity and void ratio.
\end{abstract}

Key words: Partially Saturated Soil, Residual Soil, Void Ratio, Weathering

\section{INTRODUCTION}

Negative pore water pressure or matric suction is one of the main stress variables in unsaturated soil mechanic theory [1, 2]. The existence of matric suction will increase the shear strength of the soil. A deep ground water table condition is normal in hilly area. In this case, the negative pore water pressure or matric suction plays an important role in controlling the soil shear strength and consequently the stability of many steep slopes. Shallow landslides often occur in steep residual soil slopes after heavy and prolonged rainfall.

Rainfall is considered the cause of majority of slope failures and landslides that happened in regions experiencing high seasonal rainfalls [3, 4]. When water starts to infiltrate into the soil, the matric suction especially near the ground surface will slowly reduce and become zero as the soil approaches saturated condition. The significant reduction in matric suction due to the infiltration causes a decrease in the soil shear strength that subsequently produces shallow landslides. But since infiltration is often not measured off directly from the field, its assessment often relies on vague correlation with rainfalls and runoff. Conventionally, infiltration of water is not included in slope stability analysis. Many of the slopes were designed based on experiences. However some attempts have been made to include rainwater infiltration and partial saturation in slope stability analysis [5-10]. In most of these analyses, the infiltration rate of the water into soil is assumed uniform throughout the slope.

In tropical countries such as Malaysia, the residual soil forming processes are very active. Residual soils are products of the insitu weathering of igneous, sedimentary and metamorphic rocks. The process of weathering varies with the depth or exposure of the soils. Because weathering proceeds from the surface down and inwards from joint surfaces and other percolation paths, the intensity of the weathering generally reduces with increasing depth. Most of the slopes in Malaysia that cut through the residual soil will expose the various weathering grades of the soil [11]. Due to the complexity of the weathering grades of the residual soil (which includes differences of particle size, density, mineral contents and void ratios), the infiltration of the slopes is expected to vary from point to point down the slope.

Field Test Site: The field site was a road cut at KM 31 along the Kuala Lumpur-Karak highway, near Kuala Lumpur, Malaysia. The particular road cut was made in a residual soil that had developed over the more commonly outcropping Perm-Triassic Mesozonal granite [12]. The cross section of the cut slope is shown in Fig. 1. The particular cut has been made in residual soil/rock of weathering VI to II, according to commonly used weathering classification for igneous and some sedimentary and metamorphic rocks as shown in Table 1. Detail description on the origin, formation, occurrence and typical properties of tropical residual soils can be found in Singh and Huat [13].

Laboratory and Field Tests: A series of the laboratory tests had been performed on disturbed sample, collected from the field site for their basic engineering properties. These tests include particle size distribution tests (wet sieve and hydrometer) and x-ray diffraction for clay mineralogy. In addition, in situ density tests using sand replacement method were also carried out. All the tests were performed in accordance to BS1377:1990 [15]. The results obtained are summarized in Table 2 .

For measuring the soil infiltration rate, the Geonor P-88 infiltrometer was used in this study. The field measurement is still believed to a better method to measure water infiltration rate due to the great number of variables in the infiltration process. 
Table 1: Classification of the Weathering Profile (after McLean and Gribble [14])

\begin{tabular}{lll}
\hline Weathering classification & Grade & Description \\
\hline Residual soil & VI & $\begin{array}{l}\text { All rock material is converted to soil; the mass structure and } \\
\text { material fabric are destroyed; there is a large change in volume but } \\
\text { the soil has not been significantly transported. }\end{array}$ \\
\hline Completely Weathered & V & $\begin{array}{l}\text { All rock material is decomposed and/or disintegrated to soil; the } \\
\text { original mass structure is still largely intact. }\end{array}$ \\
\hline Highly Weathered & IV & $\begin{array}{l}\text { More than half of the rock material is decomposed and/or } \\
\text { disintegrated to soil; fresh or discolored rock is present either as a } \\
\text { discontinuous framework or as core stones }\end{array}$ \\
\hline Moderately Weathered & III & $\begin{array}{l}\text { Less than half of the rock material is decomposed and/or } \\
\text { disintegrated to soil; fresh or discolored rock is present either as a } \\
\text { discontinuous framework or as core stones }\end{array}$ \\
\hline Slightly Weathered & II & $\begin{array}{l}\text { Discoloration indicates weathering of rock material and } \\
\text { discontinuity surfaces; weathering may discolor all the rock } \\
\text { material. }\end{array}$ \\
\hline Fresh Rock & I & $\begin{array}{l}\text { No visible sign of rock material weathering; perhaps slight } \\
\text { discoloration on major discontinuity surfaces }\end{array}$ \\
\hline
\end{tabular}

Table 2: Basic Engineering Properties of the Soils at Field Site

\begin{tabular}{lccccc}
\hline & Grade VI & Grade V & Grade VI & Grade III & Grade III* - II \\
\hline Specific Gravity & 2.61 & 2.63 & 2.59 & 2.59 & 1.44 \\
Bulk Density $\left(\mathrm{Mg} / \mathrm{m}^{3}\right)$ & 1.89 & 1.79 & 1.38 & 1.28 & 1.50 \\
Dry Density $\left(\mathrm{Mg} / \mathrm{m}^{3}\right)$ & 1.67 & 1.61 & 1.27 & 1.01 & 1.41 \\
Void Ratio & 0.57 & 0.63 & 1.04 & 0.50 & 0.85 \\
Porosity & 0.36 & 0.39 & 0.51 & 5.4 & 0.46 \\
Clay Content \% & 48.1 & 17.3 & 6.8 & 22.0 & 2.4 \\
Silt Content \% & 8.8 & 25.7 & 11.3 & 70.8 & 58 \\
Sand Content \% & 43 & 51.3 & 77.2 & 1.8 & 10.7 \\
Gravel Content \% & 0.1 & 5.7 & 4.7 & &
\end{tabular}

* Lower boundary of grade 3

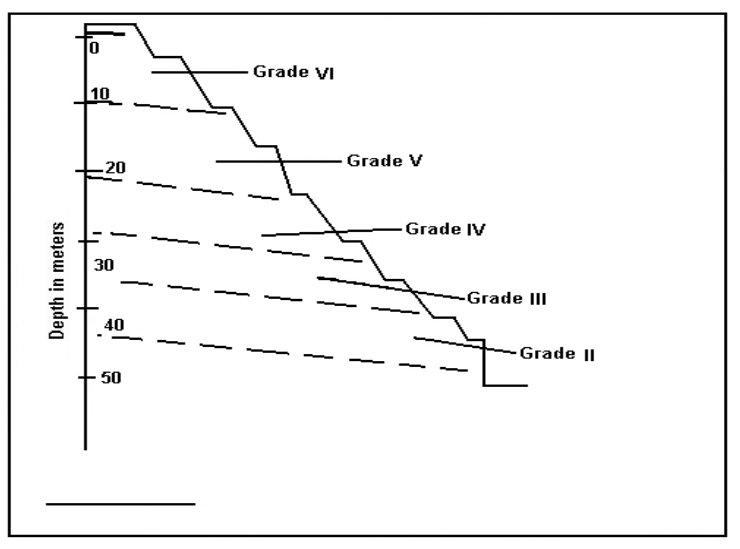

Fig. 1: Weathering Profile of the Cut Slope under Study

A schematic diagram of the test equipment is shown in Fig. 2. The water level is kept constant in the test pit with cross sectional area of $25 \times 25 \mathrm{~cm}$. Water infiltrates into the soil through the walls and the bottom

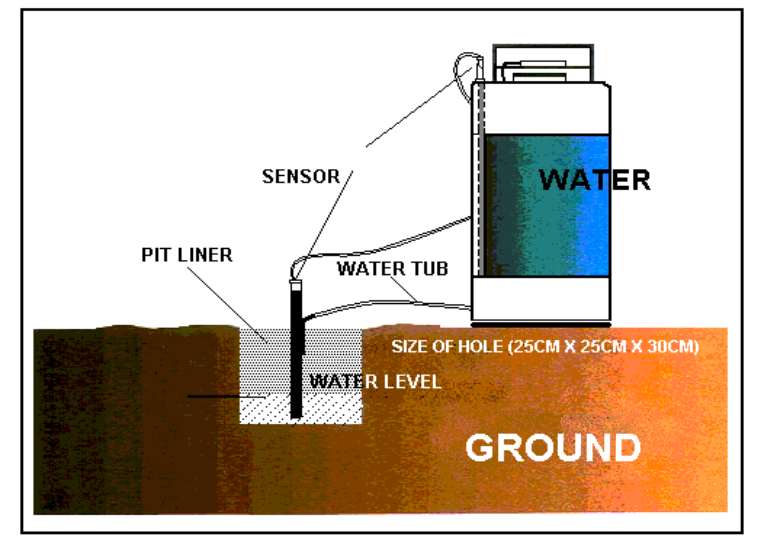

Fig. 2: Field Infiltration Test

of the pit. Normally the rate of the infiltrating flow will decrease during the test, until a steady state is achieved. This steady state flow is used to calculate the infiltration rate. The normal test duration is between 35 to $60 \mathrm{~min}$. 


\section{RESULTS AND DISCUSSION}

The infiltration tests were carried out on granitic residual soil of weathering grade III to grade VI. The test however could not be carried out on residual soil of weathering grade II since it consisted mainly of rock material. Figure 3 and 4 showed the results obtained from soils of the upper and lower boundary of weathering grade III. For residual soils of weathering grade IV, V and VI, the result are shown in Fig. 5-7, respectively.

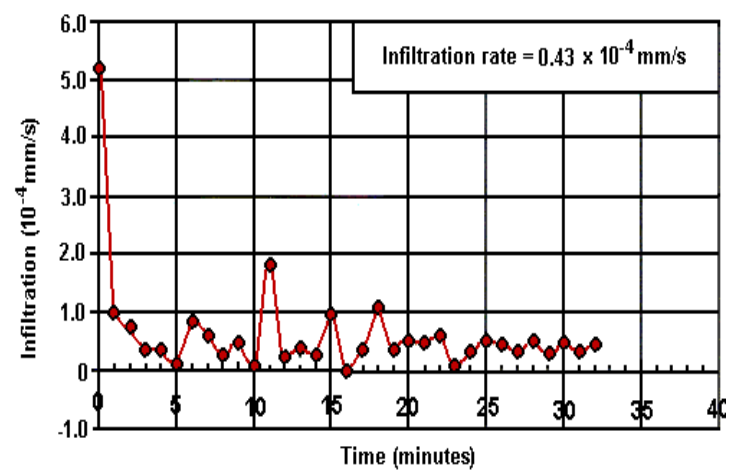

Fig. 3: Infiltration Rate of Granitic Residual Soil of Weathering III (Upper Boundary)

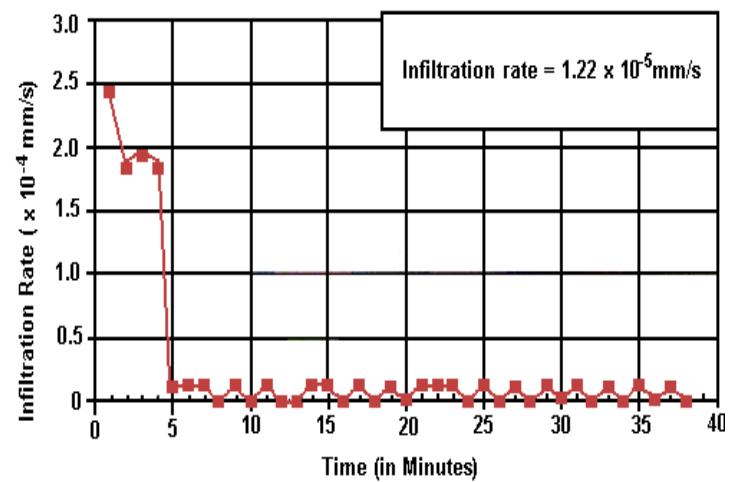

Fig. 4: Infiltration Rate of Granitic Residual Soil of Weathering Grade III - Lower Boundary

From the study it is observed that the infiltration pattern with respect to time is almost the same; initially the rate is high then it stabilizes at a lower infiltration rate. This could be explained as follow:

There is a difference in suction head in the soil. When the infiltration test is carried out, initially the surface of the test point (top layer) becomes wetter than the lower layers. Due to the difference in the suction head, downward forces (due to the suction head (capillary effect) and pressure head (moisture gradient) from the saturated top layer) with the gravity force will act on the water and force the water to infiltrate into the soil. At the beginning of the infiltration, the downward forces are large compared with the flow resistance of

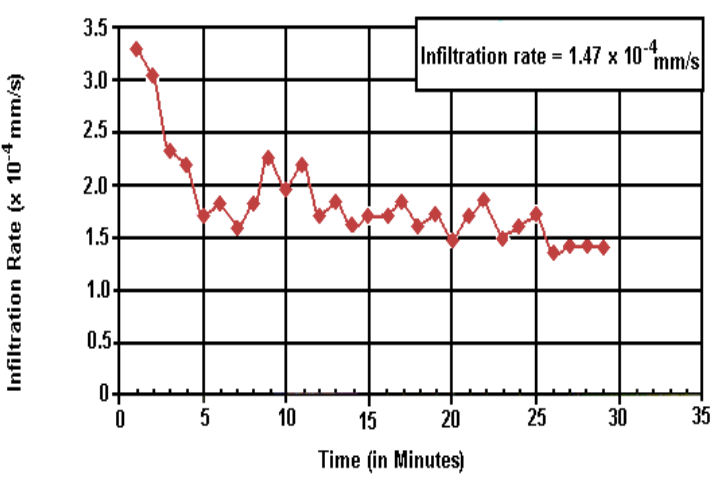

Fig. 5: Infiltration Rate of Granitic Residual Soil of Weathering Grade IV

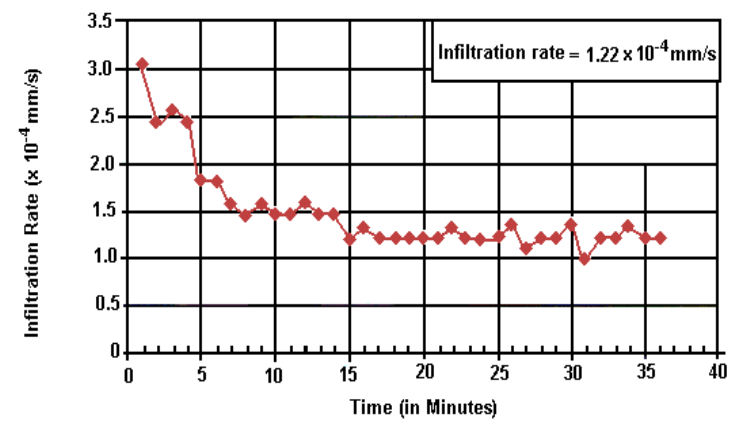

Fig. 6: Infiltration Rate of Granitic Residual Soil of Weathering Grade V

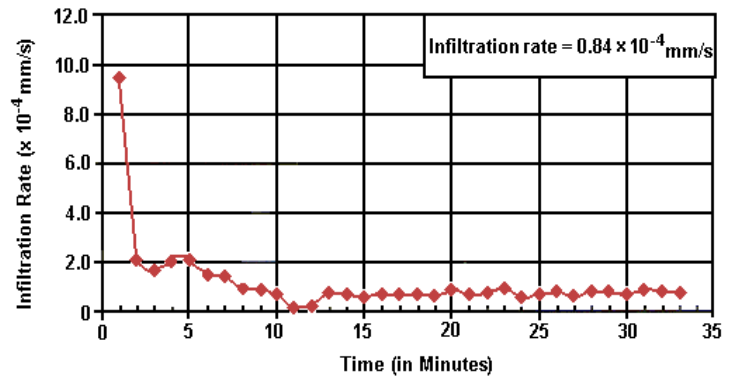

Fig. 7: Infiltration Rate of Granitic Residual Soil of Weathering Grade VI

the soil and water enters the soil rapidly. Nevertheless, with the passage of time, resistance that is caused by swelling of clay particles and entrapped air increases. Therefore, there is not much difference between the values of downward forces and thus, the rate of infiltration reduces. When the downward forces and resistance have equalized, the rate of infiltration becomes constant and stabilizes.

The stabilized infiltration rates of soil (granitic residual soils) of the various weathering grades are summarized in Table 3. The table shows that the infiltration rate varies from one weathering grade to another. The Grade IV materials show the highest infiltration rate. Moving from weathering VI to grade III, the infiltration rate increases and reduces after grade IV. 
Table 3: Infiltration Rates of Granitic Residual Soils of Various Weathering Grades

\begin{tabular}{lccc}
\hline Weathering Grade & Infiltration Rate $(\mathrm{mm} / \mathrm{s})$ & Porosity, $\mathrm{n}$ & Void Ratio, e \\
\hline Grade VI & $0.84 \times 10^{-4}$ & 0.36 & 0.57 \\
Grade V & $1.22 \times 10^{-4}$ & 0.39 & 0.63 \\
Grade IV & $1.47 \times 10^{-4}$ & 0.51 & 1.04 \\
Grade III Upper Boundary & $0.43 \times 10^{-4}$ & 0.50 & 1.01 \\
Grade III Lower Boundary & $0.12 \times 10^{-4}$ & 0.46 & 0.85 \\
\hline
\end{tabular}

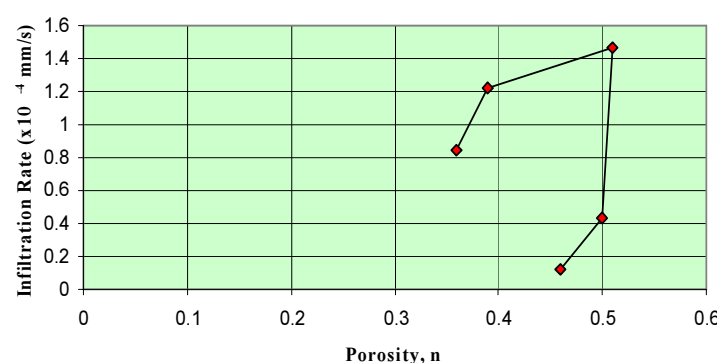

Fig. 8: Infiltration Rate vs. Porosity of Granitic Residual Soil

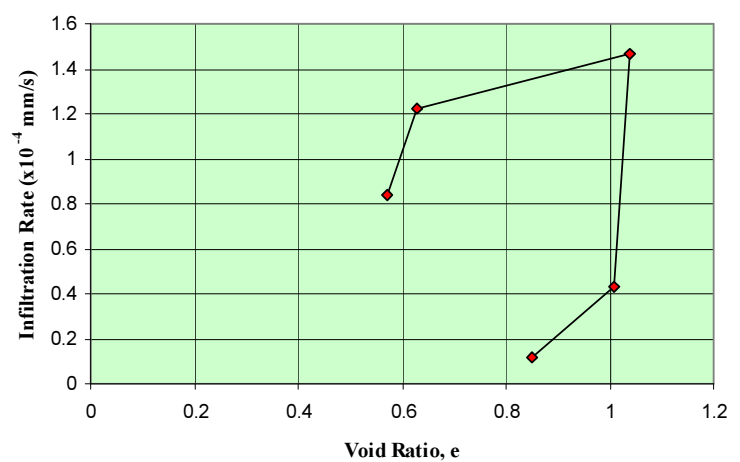

Fig. 9: Infiltration Rate vs. Void Ratio of Granitic Residual Soil Density

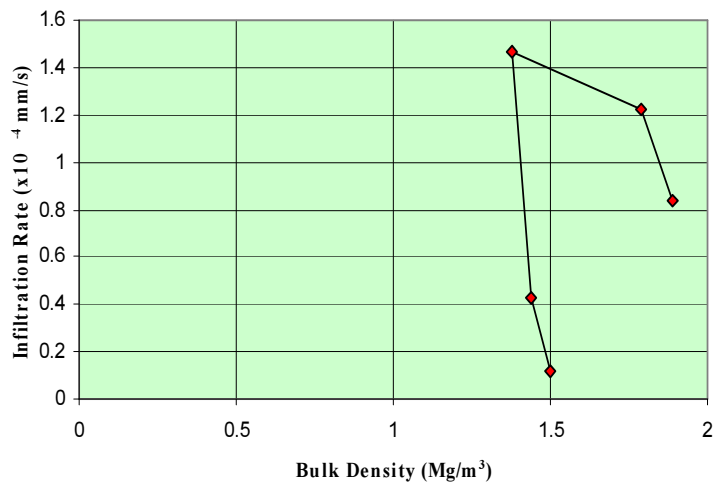

Fig. 10: Infiltration Rate vs. Bulk Density of Granitic Residual Soil

The reasons of this could be explained by examining the following soil parameter namely soil porosity and void ratio, density and soil particle content.

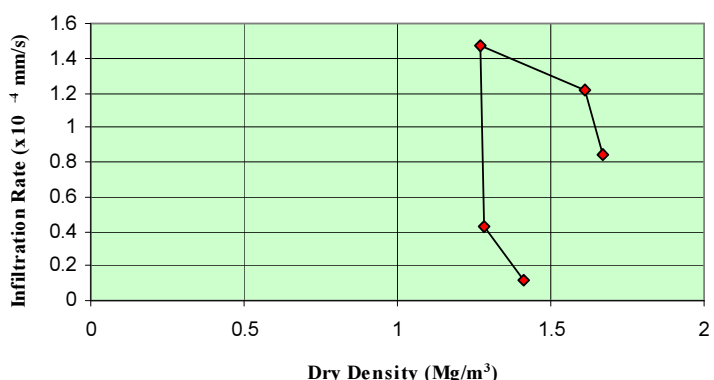

Fig. 11: Infiltration Rate vs. Dry Density of Granitic Residual Soil Soil Particles Content

Soil Porosity and Void Ratio: The soil porosity is expected to have a close relationship with the hydraulic conductivity of the soil. Hydraulic conductivity is one of the flow parameters in infiltration analysis. Overall, the higher the porosity, the higher the infiltration rates will be. Table 3 shows that the variation of the porosity of residual soil with different weathering grades matches well with the infiltration rates obtained. Residual soil of weathering grade of IV shows the highest porosity and infiltration rate compared with the other grades.

The relationship of porosity of soil with the water infiltration rate is plotted in Fig. 8. From the figure it can be seen that the water infiltration increases with the increase in the porosity of the soils. The relationship of porosity and water infiltration however is not linear. Water infiltration appears to increase rapidly when the porosity is more than 0.5 .

Void ratio would have a direct relationship with soil porosity. The relationship of void ratios with water infiltration is expected to be similar to that of the soil porosity (Table 3). The rate of water infiltration increases rapidly when the void ratio more than 1 (Fig. 9).

Figure 10 and 11 show the relationship of bulk density and dry density of the residual soil with water infiltration rates. The figure shows the higher the soil densities, the lower the rate of water infiltration and vice versa. The higher the density, the denser the soil and lesser pores or water passage in the soil, thus the infiltration reduces.

As rock goes through the weathering processes to form residual soils generally, the higher weathering grades would have soil with higher finer particles. Beside the 
soil properties mentioned above, fine particles play an important role in affecting the water infiltration. As shown in Table 2, a grade VI material has more fines (silt and clay) compared with the others. Kirby [16] suggested that the clay particles in the soil could experience swelling and block some of the pores or reduce the pore size in the soil structure during the water infiltration process.

The combination of the soil particles also affects the water infiltration. A well-distributed soil particle will give a denser arrangement, which cause a lower porosity and reduce the water infiltration. For example soil of weathering grade III have little amount of clay content but still have lower infiltration rate. In this zone least amount of weathering has occurred, it seems that the water paths are less thereby reducing the capacity of the water to infiltrate.

\section{CONCLUSION}

From the results of this study, the following conclusions could be drawn concerning the infiltration characteristics of granitic residual soils of various weathering grades.

The infiltration pattern with respect to time is almost the same for all tests conducted; initially the rate is high then it stabilizes at a lower infiltration rate.

Water infiltration rate is found to vary in soils of different weathering grades. Granitic residual soil of weathering grade IV is found to have the highest infiltration rate. Water infiltration is found to increase from grade VI to IV and decrease from grade IV to the lower grades, i.e. grade III of the upper and lower boundary.

Water infiltration increases with increase in the soil porosity and void ratio. High soil porosity or void ratios allow water to flow easily in the soil and ease the infiltration process.

Water infiltration decreases with the soil density. The higher the density, the lower the void ratio and porosity, thus the lower the water infiltration.

\section{REFERENCES}

1. Fredlund, D.G. and N.R. Morgenstern, 1977. Stress state variables for unsaturated soils. J. Geotechnical Engineering Division, ASCE, 103: 447-466.

2. Fredlund, D.G. and H. Rahardjo, 1987. Soil mechanics principles for highway engineering in Arid regions. In Soil Mechanics Considerations: Arid and Semiarid Areas. Transportation Research Record, 1137: 1-11.
3. Brand E.W., 1984. Landslide in Southeast Asia. Proceedings of $4^{\text {th }}$ International Conference on Landslide. State of the Art Report. Toronto, 1: 17-59.

4. Shaw-Shong, L., 2004. Slope failures in tropical residual soil. Chapter 5 in Tropical Residual Soils Engineering. Huat et al. (Ed). Balkema. Taylor and Francis, UK, pp: 71-102.

5. Anderson, M.G. and S. Howes, 1985. Development and application of combined soil water - slope stability model. Quart. J. Eng. Geol., 18: 225-236.

6. Anderson, M.G., M.J. Kemp and D.M. Llyod, 1988. Refinement of hydrological factors for design of cut slope in tropical soils. Proceedings $5^{\text {th }}$ International Conference on Landslide. Laussanne, 1: 525-530.

7. Othman, M.A., 1989. Highway cut slope instability problem in West Malaysia. Ph.D. Thesis. University of Bristol, (Unpublished).

8. Abdullah, A. and F.H. Ali, 1994. Field measurement of soil suction. Proceedings of $13^{\text {th }}$ International Conference on Soil Mechanics and Foundation Engineering. New Delhi, 3: 1013-1016.

9. Suhaimi, A.T., 1997. Comparative study of infiltration in residual soils. Proceeding $4^{\text {th }}$ Regional Conference in Geotechnical Engineering (Geotropika 97). Malaysia, pp: 343-354.

10. Ali, F.H. and H. Rahardjo, 2004. Unsaturated residual soil. Chapter 4 in Tropical Residual Soils Engineering. Huat et al. (Ed). Balkema, Taylor and Francis, UK, pp: 57-72.

11. Huat, B.B.K., S.S. Gue and F.H. Ali, (Eds.) 2004. Tropical Residual Soils Engineering. Balkema, Taylor and Francis, UK.

12. Raj, J.K., 1985. Characterization of the weathering profile developed over porphyritic biotite granite in Peninsular Malaysia. Bulletin of the International Association of Engineering Geology. Paris, 32: 121-127.

13. Singh, H. and B.B.K. Huat, 2004. Origin, formation and occurrence of tropical residual soils. Chapter 1 in Tropical Residual Soil Engineering. Huat et al. (Eds). Balkema. Taylor and Francis, UK, pp: 1-20.

14. McLean, A.C. and C.D. Gribble, 1979. Geology for Civil Engineers. London: E and FN Spon.

15. BSI, 1990. BS1377. Soil for civil engineering purposes. British Standards Institution.

16. Kirby, M.J., 1976. Infiltration, through Flow and Overland Flow. Introduction to Physical Hydrology. Chorley, R.J. (Ed). Methuen and Co. Ltd. 